International Journal of Environment, Agriculture and Biotechnology
Vol-6, Issue-1; Jan-Feb, 2021
Journal Home Page Available: https://ijeab.com/
Journal DOI: $10.22161 /$ ijeab

\title{
Junkshop Industry as Waste Recycling Business: A Green Response towards Economic Sustainability and Social
} Responsibility

\author{
Felipe E. Balaria, Jennifer G. Fronda, Elsie G. Baligod, Shirley R. Santiago, Carmela T. \\ Sula, Eleah Vida V. Pelayo
}

Nueva Ecija University of Science and Technology, Cabanatuan City, Philippines

Received: 08 Nov 2020; Received in revised form: 26 Dec 2020; Accepted: 03 Jan 2021; Available online: 11 Jan 2021

(C)2021 The Author(s). Published by Infogain Publication. This is an open access article under the CC BY license

(https://creativecommons.org/licenses/by/4.0/).

\begin{abstract}
This study was conducted to assess the junkshop industry in Cabanatuan City, Philippines. It aimed to determine the profile of junkshops, the materials they trade, and their compliance with legal requirements. Using descriptive qualitative research design with 20 randomly chosen participating junkshops as respondents, the researcher found out that junk shop operations are lucrative and can help support economic development as well as solve certain environmental issues. However, many of them were operating without registering with the concerned authorities. Aggressive involvement of the LGUs, by organizing junkshop operators, and close monitoring of junkshop operations are few from among the recommendations of the study.
\end{abstract}

Keywords - Junkshops operation, a requirement for junkshop operation, environmental benefits.

\section{INTRODUCTION}

Junkshop business is a simple but lucrative business that many would not want to enter in the Philippines due to its "scrappy" nature as it deals with rejects and unclean or soiled materials that are usually smelly (Business Diary PH, 2018).

The junkshop business is very relevant these days when the campaign for environmental awareness, proper waste disposal, and recycling is most aggressive due to garbage's presumed contribution to the pollution that usually results in flooding in most areas especially prevalent in the Philippines.

According to Fridman (2016), the scrap industry does not get a lot of attention. According to him, although the industry is not glamorous, it can earn multi-million dollars and contribute to the recycling industry in a way. $\mathrm{He}$ implied that this far-from-being glamorous industry can earn a million dollars while at the same time contributes to the world's recycling industry.

Anlacan (2012) enumerated that scrap trading business requires the following to succeed: sufficient capital of at least two hundred thousand pesos $(4,000 \mathrm{U} \$)$ for purchasing scarps and for space rentals; knowledge of and focus on the kind of scraps to trade like metal, paper, glass, and plastics; a suitable location on where to buy and store scraps; business registration and permits from the barangay or municipal hall, and Bureau of Internal Revenue registration for receipts; list 'of good buyers to ensure the best offer for your scarps; good working relationship with at least two buyers for better leverage; knowledge of the going, buying and selling prices of scraps; proper equipment like weighing scale and delivery vehicle; and thorough knowledge of the business operation.

To start the business, the Filipino Entrepreneur (2010) stated that it would be best to have: potential clients; a walk- 
in procedure to avoid pilferage; and daily accounting to determine what scrap needs to be maintained or replenished day by day. Like Anlacan, the Filipino Entrepreneur also believes that thorough knowledge about the trading process of scrap is necessary.

Junkshop owners and operators probably did not know that their business help in the reduction of trash builds-up in the community. It is a win-win solution that probably for both the owners and the scavengers. The scavengers "explore" their trash mounds, trash bags, and trash bins for anything recyclables they can sell to the junkshops where they get money for it. The junkshop operators who buy scraps provide an opportunity for the living of these scavengers, and the community without being mindful of it gets freed from more serious trash problem.

It is assumed that if only the number of those who indulge in the junkshop business would increase, dumped junks will not clog some areas, and thus, flooding would be prevented somehow.

This study presumes that if only many would indulge in the junkshop business, the more they could earn money while providing a source of livelihood to the scavengers as they help clean the community at the same time. However, since the job is dirty, only a few engage in it. Probably, if many would see and read about the potential of the business, many would go into it; hence this study.

\section{STATEMENT OF THE PROBLEM}

The study focused on scrap business in Cabanatuan City, Philippines as a green response to economic stability and social responsibility.

It specifically aimed to determine the following:

1. The profile of junkshops in Cabanatuan City in terms of :
1.1 building structure;
1.2 lot area;
1.3 capital investment

2. The scrap materials in the junkshop in terms of:

\section{1 specifications; and \\ 2.2 buying and selling price}

3. The operations of the junk shops in terms of registration with the authorized government agencies.

\section{METHODOLOGY}

This study used a descriptive survey design using a total enumeration of 20 junkshop owners as respondents. A descriptive survey design was employed because the study surveyed to describe the junkshop business as it existed at the time of the study. Total enumeration was used because there were only a limited number of junkshop operators in the city. Meanwhile; the primary tool used to gather data was a survey questionnaire triangulated by personal interview using an interview guide. For data analysis, descriptive statistics such as frequency, mean, and percentage were used.

\section{RESULTS AND DISCUSSION}

The following were the findings of the study:

1. Profile of Junkshops in Cabanatuan City

Table 1 would show the detailed findings of the profile of the junkshops.

\subsection{Building structure}

It can be seen from Table 1 that in terms of building structure, wherein the junkshops surveyed were classified as to concrete or permanent and light or temporary, five (5) or $25 \%$ were housed in concrete structures while 15 or 75 percent were housed in structures made of light materials.

It can be recalled that in 1978, the Philippine government had set an occupational safety standard in compliance with the constitutional mandate to safeguard the workers' social and economic wellbeing as well as their physical safety and health. According to OSH Standards (1989), this is considered a landmark in the Philippine labor and social legislation. Apparently, since most of the junkshops were made of light materials, it could be deduced that the junkshop industry in Cabanatuan City needs upgrading to ensure that they would not pose a threat to the safety of the workers and its adjoining structures.

Table 1. Profile of the Junkshops in Cabanatuan City

\begin{tabular}{|c|c|c|}
\hline 1.1 Building structure materials & $f$ & $\%$ \\
\hline Light & 15 & 75 \\
\hline Concrete & 5 & 25 \\
\hline 1.2 Lot area & 20 & $100 \%$ \\
\hline$<1,000$ sq.m. & & \\
\hline $1,001-2,000$ sq.m. & 5 & 65 \\
\hline
\end{tabular}




\begin{tabular}{|c|c|c|}
\hline \multirow[t]{2}{*}{$2,001-3,000$ sq.m. } & 2 & 10 \\
\hline & 20 & $100 \%$ \\
\hline 1.3 Capital investment & & \\
\hline$<$ Php 100,000 & 12 & 60 \\
\hline $\begin{array}{l}-4,000 \mathrm{U} \$) \\
100,001-200,000(2,000\end{array}$ & 4 & 20 \\
\hline $200,001-300,000$ & 2 & 10 \\
\hline $300,001-400,000$ & 2 & 10 \\
\hline$>\mathrm{Php} \quad 400,001$ & 0 & - \\
\hline & 20 & $100 \%$ \\
\hline
\end{tabular}

\subsection{Lot Area of the Junkshops}

Table 1 further shows that the majority of the junkshops; comprising 13 or $65 \%$ occupy a lot area of 1000 sq. m. and below. The second majority comprising five (5) or $25 \%$ occupies an area that ranges from $1,021 \mathrm{sqm}$ to $2,020 \mathrm{sq}$. $\mathrm{m}$. The rest, comprising only two (2) or $10 \%$ occupies a lot area between 2001 to 3000 sq. $\mathrm{m}$.

The above figures imply that majority of the junkshops are not complying with the 2,000 sq. m. minimum lot area required for junkshops. This would mean that with the current situation of the junkshops, there would be a tendency for lesser movement between files of scraps and a tendency as well that in just a slight error an avalanche might happen and the workers may get buried alive beneath the scraps.

Another implication is that the situation would require a faster turnover of scrap materials from sellers to buyers so that there would be a larger space left inside the shop. This would decrease the chances of accidents but may require frequent transportation that in turn would also require an increased transportation budget.

\subsection{Capital Investment}

Evidently, the scrap business in Cabanatuan City is still in its infant stage considering that the capital investment of the majority, 12 or $60 \%$ was only 100,000 pesos. Fewer, comprising four or $20 \%$, were able to put up the minimum capital requirement of at least 200, 000 pesos. Only the remaining four (4) or $20 \%$ were able to put capital investment above the minimum requirement.

The above figures suggest that most of the junkshop operators in the City were small players. Interviews revealed that most of those who are engaged in the business do not have the financial capacity to invest enough to operate in large scale transaction. This may also bear effect on the environment because it follows that when the capital to accommodate more scraps is limited, more scraps will tend to remain in the dumping sites and landfill around the communities, posing as eyesores and threats to the environment.

2. The scrap materials in the junkshop

\subsection{Specifications}

The study revealed as can be viewed from Table 2 that the scrap materials bought by the junkshops are categorized as plastics, glass, paper, and batteries.

The study also revealed that not all the 20 junkshops buy all the specified plastics namely HDPE (high-density polyethylene), PET (polyethylene terephthalate), LDPE (low-density polyethylene), PP (polypropylene), and HIPS (high impact polyethylene). HDPE includes soap holders, food trays and crates, motor oil containers, and the likes except for cosmetic bottles. PETS include bottles of mineral water, cosmetics, and soft drinks. LDPE includes clear plastic bags, crop protection sheets, ice cream container lids, and computer covers. PPs include wastebaskets, water basins, egg trays, bottle caps, and tube caps. HIPS include disposable drinking cups and disposable spoons, forks, and knives. 
Table 2. Specifications of scraps accommodated in junkshops

\begin{tabular}{|c|c|c|c|}
\hline Specifications & $n$ & $\%$ & Buying Price/kg (Note: $1 \mathrm{U} \$=$ Php 50) \\
\hline \multicolumn{4}{|l|}{ Plastics } \\
\hline HDPE & 18 & 90 & Php $\quad 5.00-16.00(10-32$ cents U\$) \\
\hline PETS & 12 & 60 & \\
\hline LDPE & 4 & 20 & \\
\hline PP & 9 & 45 & \\
\hline HIPS & 8 & 40 & \\
\hline \multicolumn{4}{|l|}{ Glass } \\
\hline Whole glass & 20 & 100 & Php $\quad 0.50-150.00(0.01-3.00 \mathrm{U} \$)$ \\
\hline Broken glass & 20 & 100 & - \\
\hline Colored & & & Php $\quad 0.10-0.20$ \\
\hline White & & & Php $\quad 0.50-1.00$ \\
\hline \multicolumn{4}{|l|}{ Metals } \\
\hline Aluminum & 20 & 100 & Php $30.00-45.00 \quad(0.60-0.90 \mathrm{U} \$)$ \\
\hline Scrap metals & 20 & 100 & Php $1.00-4.50$ \\
\hline Copper & 20 & 100 & Php 70.00 \\
\hline Alloys & 20 & 100 & Php $30.00-45.00$ \\
\hline Brass fender & 20 & 100 & - \\
\hline Washers & 20 & 100 & - \\
\hline GI Sheets & 20 & 100 & Php $0.25-1.00$ \\
\hline Zinc & 20 & 100 & Php $8.00-15.00$ \\
\hline \multicolumn{4}{|l|}{ Paper } \\
\hline Assorted & 20 & 100 & $(16$ cents $\mathrm{U} \$)$ \\
\hline Newspaper & 20 & 100 & Php 15.00 \\
\hline Cardboard & 20 & 100 & - \\
\hline Magazine & 20 & 100 & Php 8.00 \\
\hline Office paper (white) & 20 & 100 & Php 11.00 \\
\hline \multicolumn{4}{|l|}{ Batteries } \\
\hline $1 \mathrm{SNF}$ & 20 & & Php $50.00-70.00$ \\
\hline $1 \mathrm{SMF}$ & 20 & & Php $150.00-400.00 \quad(3.00-8.00 \mathrm{U} \$)$ \\
\hline $2 \mathrm{SM}$ & 20 & & \\
\hline $3 \mathrm{SM}$ & 20 & & \\
\hline $6 \mathrm{SM}$ & 20 & & \\
\hline $2 \mathrm{D}$ & 20 & & \\
\hline $4 \mathrm{D}$ & 20 & & \\
\hline $8 \mathrm{D}$ & 20 & & \\
\hline
\end{tabular}


With the result, it could be said that if only all junkshops would buy all sorts of recyclable plastics as mentioned above, there would be no way plastics would litter the environment. Sadly, however, it was found out that not all junkshops in Cabanatuan City buy them. As can be gleaned in Table 2, only HDPE and PETS seemed to be most acceptable to buyers.

The glass bought by junkshop operators is classified as whole or broken. The broken ones are further classified as colored or white. Fortunately, all junkshops in Cabanatuan city buy all sorts of these.

Metals are also classified according to their rarity and it is very fortunate that these metals were not likely to be trashed somewhere as all can be bought by the junkshop and be recycled.

All kinds of papers, classified according to color and thickness, are also bought in the junkshops. In terms of batteries, however, it could be noted that only batteries of vehicles are accepted in junkshops.

With the above findings that show junkshop owners are buying almost all sorts of recyclable scraps, there is no doubt that they help in keeping and preserving the environment one way or the other.

\subsection{Junkshop operators' selling price}

It can also be viewed from Table 2 that the scraps bought by the junkshops get to be sold to bigger scrap traders, sometimes 100 percent higher than the cost they bought them. That is why, it can really be said that while these owners help clean the environment, they profit from the junks at the same time. Indeed, a junk shop operation can be a profitable business.

3. The operation of the junkshops in terms of government requirements

While there is a law requiring any business to get permission to operate from the local government unit (LGU), it is evident in Table 3 that the junkshop business in Cabanatuan City did not seem to be bothered by this requirement as only nine (9) of them are registered.

\begin{tabular}{|l|c|c|}
\hline Business Registration with the LGU & $\mathrm{n}$ & $\%$ \\
\hline With & 9 & 45 \\
\hline Without & 11 & 55 \\
\hline Total & 20 & $100 \%$ \\
\hline
\end{tabular}

Further analysis revealed that 45 percent of registered shops were the larger ones; the smaller ones were not registered at all and operating without giving back in the form of fees to the LGU. When interviewed about why they did not register their business, the operators said that it was difficult to secure permits because of the building requirements. But they just went on with their business albeit in the absence of a permit, and ironically their attention was not even called by authorities for operating even without the necessary permit.

The result implies that while the junk shop business may be lucrative, only the operators and the sellers seem to profit from it. The government did not receive anything in return from them in the form of tax. This finding means that since these shops operate without LGU permission, they consequently do not pay dues; so while they earn, and somehow clean the surroundings of trash, they however do not contribute to the government coffer.

The above-mentioned findings also imply that these shops may pose a threat to the safety and well- being of the shop workers because they may be subject to danger of threats and abuses without the authorities knowing it. All these because they did not seek the permission of authorities who are supposed to ensure that they operate based on standards. There is also an indication of laxity among concerned authorities.

\section{SUMMARY, CONCLUSIONS, AND RECOMMENDATIONS}

\section{Summary of findings}

1. The study revealed that the majority of the junkshops in Cabanatuan City are housed in structures made of light materials, erected in a 20 to 1000 -sq. m. areas of lot, and operate with only Php100,000 investment capital.

2. The junkshops buy almost all types of plastics, whole or broken glasses, metals, papers, and vehicle batteries. They buy junks by the kilogram, with paper as the cheapest (price ranging from 50 cents to Php15 per $\mathrm{kg}$.) and with batteries and certain types of metal as most expensive (price ranging from 50 to $70 \mathrm{Php}$ per $\mathrm{kg}$ ) They sell the scarps they bought at $100 \%$ over the price they bought them.

3. Only $45 \%$ of junkshops in Cabanatuan City were reregistered. The rest are operating informally or without permits from the local government unit and other government agencies. 


\section{Conclusions}

Based on the findings of the study, the following were thus concluded:

1. Junkshops operation in Cabanatuan City needs monitoring and control to ensure the safety of the owners, the workers, and the community they belong to.

2. Junkshop business is a lucrative endeavor that also helps in clearing the environment, preventing floods, and in preserving natural resources.

3. The communities are deprived of benefitting from taxes that the informal operators of junkshops failed to give to the LGUs by not registering.

\section{Recommendations}

Based on the findings and conclusions of the study the following are thus recommended:

1. The LGUs and other concerned authorities should pay more attention to the junkshop operations in the City through the following:

a. Close monitoring to ensure that these junkshops meet the standard requirements in terms of building structure construction, prescribed lot area, and capital investment for proper taxation. This would ensure the safety of everyone involved in the business. This will further add dignity to the trade.

b. Organizing the junkshop operators in Cabanatuan City that each member may police one another, and further ensure fair trade practice.

2. Because junkshop operation is a lucrative business that helps in maintaining cleanliness, preventing flood, and preserving natural resources, the following are suggested.

a. Junkshop operation should be encouraged to practice corporate social responsibility (Mina, et.al., 2019).

b. Junkshop owners should upgrade their strategies by offering on-call home cleaning services.

c. Massive information campaigns should be conducted to encourage the communities to segregate waste and to call the services of junkshop owners in systematically disposing of their junk.

3. The LGU's should devise ways and means to ensure that junkshops in the city are operating legally and paying their tax dues regularly.

\section{REFERENCES}

[1] Antonio, L. (2010) Study on Recyclables Collection Trends and Best Practices in the Philippines.Philippine Business for Environment, Philippines

https://www.eria.org/uploads/media/Research-ProjectReport/RPR_FY2009_10_Chapter_3.pdf

[2] Atienza, V. (2011) Review of Waste Management System in the Philippines: Initiatives to Promote Waste Segregation and Recycling through Good Governance https://www.ide.go.jp/library/Japanese/Publish/Download/Re port/2010/pdf/2010_431_05.pdf

[3] ASEAN Mayors Forum 2017 (2017) Good Practices in Waste Management from Indonesia and the Philippines. Designs for Success;Best Practices in Local Waste Management https://www.delgosea.eu/News/Good-Practices-in-WasteManagement-from-Indonesia-and-the-Philippines

[4] Asian Development Bank (2016) INTEGRATED SOLID WASTE MANAGEMENT FOR LOCAL GOVERNMENTS A Practical Guide https://www.adb.org/sites/default/files/institutionaldocument/324101/tool-kit-solid-waste-management.pdf

[5] Beninang, M. (2017) QC entices junk-shop owners to become partners in recycling. https://businessmirror.com.ph/2017/08/07/qc-entices-junkshop-owners-to-become-partners-in-recycling/

[6] Bernardo, A. (2006) Solid-wastemanagement practices of households in Manila, Philippines https://pubmed.ncbi.nlm.nih.gov/18991942/

[7] Business Diary PH (2018) How to start o junkshop and scrap business https://businessdiary.com.ph/1069/how-to-start-a-junkshopand-scrap-business/

[8] Carballo-Pago, A. (2018) These big manufacturing companies failed to give an option for poor consumers. Greenpeace Southeast Asia.

https://www.eco-business.com/news/philippines-centralgovernment-on-solving-plastic-trash-problem-weve-done-allwe-can/

[9] Castillo, A. \& Otoma, S. (2013) Statusof Solid Waste Management inthe Philippines https://www.jstage.jst.go.jp/article/jsmcwm/24/0/24_677/_pdf

[10] Ex Corporation (2008) The study on recycling industry development in the Republic of the Philippines http://nswmc.emb.gov.ph/wp-content/uploads/2018/03/FinalReport-Volume-I.pdf

[11] Gonzales, E. (2003) From wastes to assets: the scavengers of Payatas. International Conference on Natural Assets. Conference Paper Series https://www.peri.umass.edu/fileadmin/pdf/conference_papers /CDP7.pdf

[12] Mina, J.C., Barlis, P.T., Vega, N.C. and Subia, G.S. (2019) Corporate Social Responsibilities of Selected Resorts in Cabanatuan City, Nueva Ecija, Philippines. Open Access 
$\begin{array}{llll}\text { Library Journal, } & \text { 6: }\end{array}$ https://doi.org/10.4236/oalib.1105292

[13] Mongabay, B. (2018) Philippines central government on solving plastic trash problem: 'We've done all we can'. EcoBusiiness

https://www.eco-business.com/news/philippines-centralgovernment-on-solving-plastic-trash-problem-weve-done-allwe-can/

[14] Palafox, F. (2017) Ecological waste management https://www.manilatimes.net/2017/12/07/opinion/analysis/eco logical-waste-management/367117/

[15] Pepino, V. (2019) An integrated recycling industry for sustainability. BusinessWorld. August 27, 2019

https://www.bworldonline.com/an-integrated-recyclingindustry-for-sustainability/

[16] Pure Earth Blacksmith Institute (2016) REGIONAL: Mitigation of Hazardous Waste Contamination in Urban Areas: Supporting Inclusive Growth (Financed by the Japan Fund for Poverty Reduction) (Main Report, Appendix A) https://www.adb.org/sites/default/files/projectdocuments/47144/47144-001-tacr-en.pdf

[17] Roy, K. and Yu, J. (2009) Finding urban waste management solutions and policies: Waste-to-energy development and livelihood support system in Payatas, Metro Manila, Philippines.Journal of Environmental Science, Vol.1, Supplement 1, 2009, pp. S40-S43

https://pubmed.ncbi.nlm.nih.gov/25084429/

[18] Sapuay, G. (2016) Resource Recovery through RDF: Current Trendsin Solid Waste Management in thePhilippines.International Conference on Solid Waste Management, 5IconSWM 2015

[19] Wang, M. et al. (2019) A Scientometric Review of Resource Recycling Industry.International Journal of Environmental Research and Public Health. Published online Nov. 22, 2019 https://pubmed.ncbi.nlm.nih.gov/31766728/

[20] http://invest.cfo.gov.ph/pdf/part3/BSMMED/SAB-junkshopbusiness09.pdf 